\title{
Lupus anticoagulant hypoprothrombinemia syndrome associated with bilateral adrenal haemorrhage in a child: early diagnosis and intervention
}

Atsushi Sakamoto ${ }^{1,2^{*}} \mathbb{D}$, Masao Ogura ${ }^{3}$, Atsushi Hattori $^{4}$, Kinji Tada $^{1}$, Reiko Horikawa ${ }^{4}$, Hisaya Nakadate ${ }^{5}$, Kimikazu Matsumoto ${ }^{2}$, Keiji Nogami ${ }^{6}$, Masahiro leko ${ }^{7}$ and Akira Ishiguro, ${ }^{1,5}$

\begin{abstract}
Background: Lupus anticoagulant-hypoprothrombinemia syndrome (LAHPS) is characterized by bleeding and thrombosis in patients with autoimmune diseases or infections. Paediatric LAHPS exhibits various degrees of bleeding, ranging from mild to severe; however, adrenal haemorrhage due to LAHPS and its long-term clinical course have not been sufficiently described.

Case presentation: A 9-year-old boy presented with prolonged abdominal pain and abnormal coagulation screening tests. The laboratory tests showed prolonged activated partial thromboplastin time and subsequently revealed the presence of lupus anticoagulant, anti-nuclear antibodies, and hypoprothrombinemia, leading to diagnosis of LAHPS. An enhanced computed tomogram demonstrated nodular lesions in the adrenal glands bilaterally, suggestive of adrenal haemorrhage. Laboratory and clinical manifestations exhibited life-threatening adrenal insufficiency that required hydrocortisone administration. The patient developed systemic lupus erythematosus, diagnosed 12 months later.

Conclusions: This patient with LAHPS developed rare adrenal failure due to adrenal haemorrhage, a lifethreatening event that should be recognized and treated early. In our case, renal dysfunction was also observed when systemic lupus erythematosus was diagnosed 1 year after LAHPS. Our case emphasizes that early recognition of adrenal failure and careful long-term observation is required in patients with autoantibodies.
\end{abstract}

Keywords: Lupus anticoagulant, Hypoprothrombinemia, Adrenal haemorrhage, Adrenal insufficiency, Lupus anticoagulant hypoprothrombinemia syndrome

\footnotetext{
* Correspondence: sakamoto-a@ncchd.go.jp

${ }^{1}$ Center for Postgraduate Education and Training, National Center for Child

Health and Development, NCCHD, Tokyo, Japan

${ }^{2}$ Children's Cancer Center, National Center for Child Health and

Development, Setagaya-ku, Tokyo 157-8535, Japan

Full list of author information is available at the end of the article
}

C C The Author(s). 2021 Open Access This article is licensed under a Creative Commons Attribution 4.0 International License, which permits use, sharing, adaptation, distribution and reproduction in any medium or format, as long as you give appropriate credit to the original author(s) and the source, provide a link to the Creative Commons licence, and indicate if changes were made. The images or other third party material in this article are included in the article's Creative Commons licence, unless indicated otherwise in a credit line to the material. If material is not included in the article's Creative Commons licence and your intended use is not permitted by statutory regulation or exceeds the permitted use, you will need to obtain permission directly from the copyright holder. To view a copy of this licence, visit http://creativecommons.org/licenses/by/4.0/. The Creative Commons Public Domain Dedication waiver (http://creativecommons.org/publicdomain/zero/1.0/) applies to the data made available in this article, unless otherwise stated in a credit line to the data. 


\section{Background}

Lupus anticoagulant (LA) is an antiphospholipid antibody that inhibits phospholipid-dependent clotting without inhibiting the activity of individual coagulation factors, and often leads to severe thrombotic disorders [1]. Patients with concomitant acquired hypoprothrombinemia and LA, termed lupus anticoagulanthypoprothrombinemia syndrome (LAHPS), sometimes show decreased coagulation factor activity [2, 3]. Patients occasionally develop LAHPS after viral infections, and present with bleeding symptoms in the paediatric age group [2]. Patients with LAHPS exhibit various degrees of bleeding, ranging from mild mucocutaneous bleeding to life-threatening intracranial haemorrhage; however, adrenal haemorrhage resulting from LAHPS and its long-term course have only been described rarely [3-5].

Adrenal insufficiency is a potentially life-threatening event, and may result from adrenal haemorrhage [6]. Despite its risk for severe morbidity or mortality, signs and symptoms are subtle and the diagnosis is often delayed [6]. Early recognition of adrenal haemorrhage enables early intervention, and the patient can be managed successfully without endocrine shock after adrenal insufficiency.

We report a rare case of progression of LAHPS into systemic lupus erythematosus (SLE) in a Japanese boy who had severe acute adrenal failure due to bilateral adrenal haemorrhage.

\section{Case presentation}

A 9-year-old boy had normal perinatal history, growth, and development. He presented with a fever, abdominal pain, and vomiting, all starting 5 days before admission. Diarrhea and hematochezia were not noted. We examined a stool sample to test for bacterial pathogens, which were not detected. His condition was provisionally diagnosed as acute viral gastroenteritis based on the clinical manifestations. On admission, his vital signs were body temperature $38.0^{\circ} \mathrm{C}$, blood pressure $98 / 44 \mathrm{mmHg}$, heart rate $82 / \mathrm{min}$, and respiratory rate $16 / \mathrm{min}$ with an $\mathrm{O}_{2}$ saturation of $99 \%$ on room air. Upper abdominal tenderness was found without abdominal swelling or hepatosplenomegaly. Complete blood count showed white blood cells $9540 / \mu \mathrm{L}$, haemoglobin $13.9 \mathrm{~g} / \mathrm{dL}$, and platelets $140 \times 10^{3} / \mu \mathrm{L}$. Biochemical parameters showed total bilirubin $0.56 \mathrm{mg} / \mathrm{dL}$, aspartate transaminase $58 \mathrm{IU} /$ $\mathrm{L}$, alanine transaminase $47 \mathrm{IU} / \mathrm{L}$, blood urea nitrogen 6.3 $\mathrm{mg} / \mathrm{dL}$, creatinine $0.23 \mathrm{mg} / \mathrm{dL}$, sodium $134 \mathrm{mEq} / \mathrm{L}$, potassium $4.1 \mathrm{mEq} / \mathrm{L}$, and C-reactive protein (CRP) 3.7 $\mathrm{mg} / \mathrm{dL}$. Coagulation studies revealed prolonged activated partial thromboplastin time (aPTT) of $92.4 \mathrm{~s}$, elevated Ddimer $3.7 \mu \mathrm{g} / \mathrm{mL}$, LA positivity, and slightly low
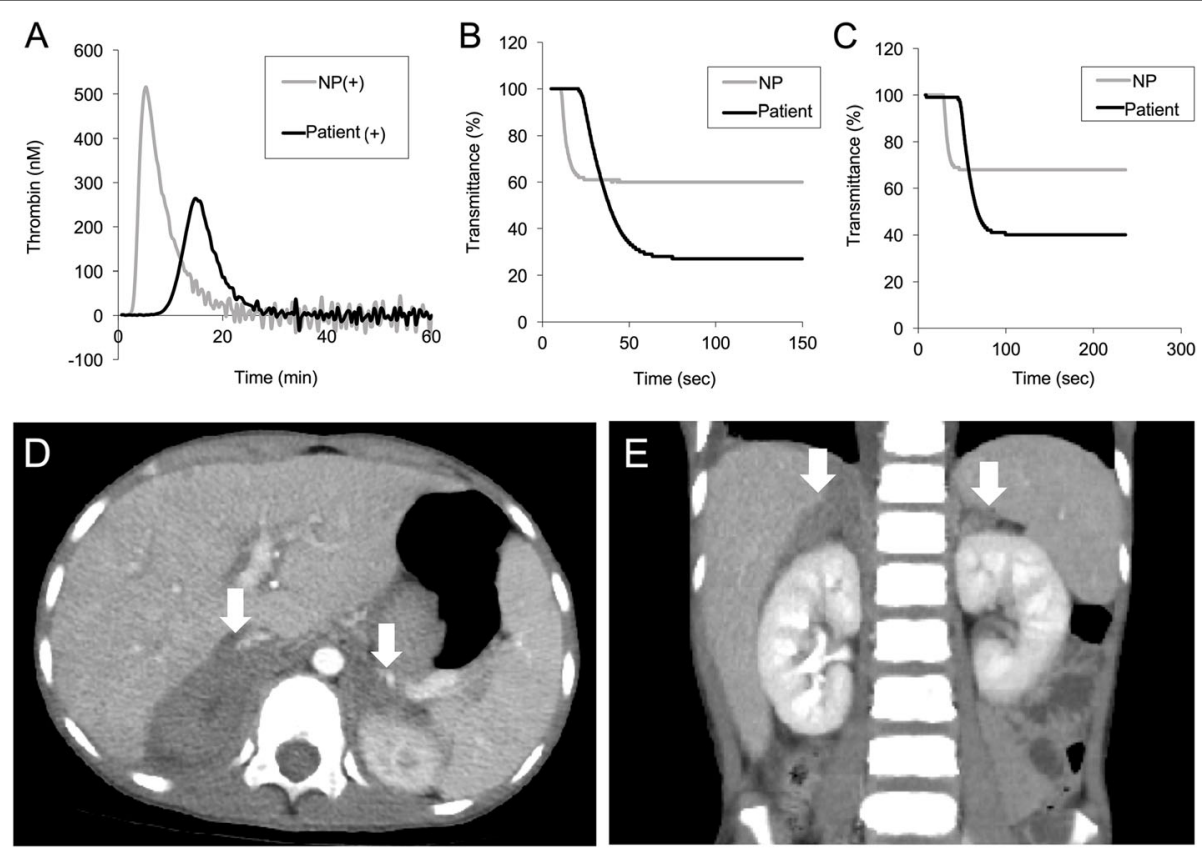

Fig. 1 a Thrombin generation assay which monitors one-step before fibrin formation. In contrast to a healthy control, the lag time in lupus anticoagulant (LA)-positive serum was delayed. The peak thrombin level in the patient was lower than in the control. $\mathbf{b}$ and $\mathbf{c}$ Clot waveform analyses were evaluated by fibrin formation. The clot times in LA-positive serum were significantly prolonged compared to a healthy control. $\mathbf{b}$, prothrombin time; c, activated partial thromboplastin time. $\mathbf{d}$ and $\mathbf{e}$ Contrast abdominal computed tomograms show nodular lesions in the enlarged adrenal glands bilaterally, indicating adrenal haemorrhage (arrows). d, Axial; e, Coronal 
prothrombin activity 58\% (reference range [RR] 75$135 \%$ ) in combination with immunoglobin M (IgM) class anti-prothrombin antibody of $32.1 \mathrm{AU} / \mathrm{mL} \quad(\mathrm{RR}<24.0$ $\mathrm{AU} / \mathrm{mL}$ ). Immunoglobin $\mathrm{G}$ (IgG) class antiphosphatidylserine/prothrombin antibody was also positive ( $>50.0$ units, $R R<2.0$ units), which is associated with strong LA activity. The patient's LA-positive plasma was examined using the thrombin generation test and clot waveform analyses (Fig. 1a, b, and c) as previously described [7]. The clotting times in LA-positive plasma were significantly prolonged, compared to a healthy control.

A diagnosis of LAHPS was made. The patient tested positive for anti-nuclear antibody (ANA) titer 1:160, anti-double-stranded DNA (dsDNA) antibody of IgG 22 $\mathrm{IU} / \mathrm{mL}$, anticardiolipin antibody of $\operatorname{IgG} 16 \mathrm{U} / \mathrm{mL}$, and anti- $\beta 2$-glycoprotein I antibody of IgG $>50$ units, but the patient did not fit the Systemic Lupus International Collaborating Clinics (SLICC) 2012 Classification Criteria [8]. A contrast-enhanced computed tomogram revealed nodular lesions in the adrenal glands bilaterally (Fig. 1d and e). The diagnosis of acute adrenal failure due to adrenal haemorrhage was made on the basis of the clinical manifestations, mild hyponatremia $(134 \mathrm{mEq} / \mathrm{L})$, high plasma ACTH $1586 \mathrm{pg} / \mathrm{mL}$ (RR 7.2-63.3), low plasma cortisol $3.24 \mu \mathrm{g} / \mathrm{dL}$ (RR 6.2-18.0), blood glucose $37 \mathrm{mg} /$
$\mathrm{dL}$, low serum aldosterone $43.1 \mathrm{pg} / \mathrm{mL}$, and relatively elevated plasma renin activity $9.1 \mathrm{ng} / \mathrm{mL} / \mathrm{hr}$. Hence, the patient received glucose $(0.6 \mathrm{~g} / \mathrm{kg} /$ dose), hydration (1700 $\left.\mathrm{mL} / \mathrm{m}^{2}\right)$, and hydrocortisone $\left(50 \mathrm{mg} / \mathrm{m}^{2} /\right.$ day). Hydrocortisone and fludrocortisone were continued for the adrenal replacement therapy at physiological doses. Repeated coagulation studies still showed positive LA and prolonged aPTT for 12 months (Fig. 2a).

At 10 years of age, he visited our hospital because of gait disturbances and weakness in all extremities after acute upper respiratory viral infection. He had butterfly rash, discoid rash, optic disc swelling, deranged renal function, and showed higher levels of ANA and antidsDNA antibody. Renal biopsy resulted in a diagnosis of lupus nephritis (Fig. 2b and c). His condition was diagnosed as SLE on the basis of the SLICC 2012 Classification Criteria [8]. Intravenous pulsed treatments with methylprednisolone $(30 \mathrm{mg} / \mathrm{kg} /$ day $)$ and cyclophosphamide $\left(500 \mathrm{mg} / \mathrm{m}^{2}\right)$ were immediately initiated, followed by mycophenolate mofetil $400 \mathrm{mg} / \mathrm{m}^{2} /$ day. The patient's clinical condition improved.

\section{Discussion and conclusions}

The present case provides two clinical messages: 1) early diagnosis and treatment are crucial for a favorable outcome after adrenal failure following adrenal

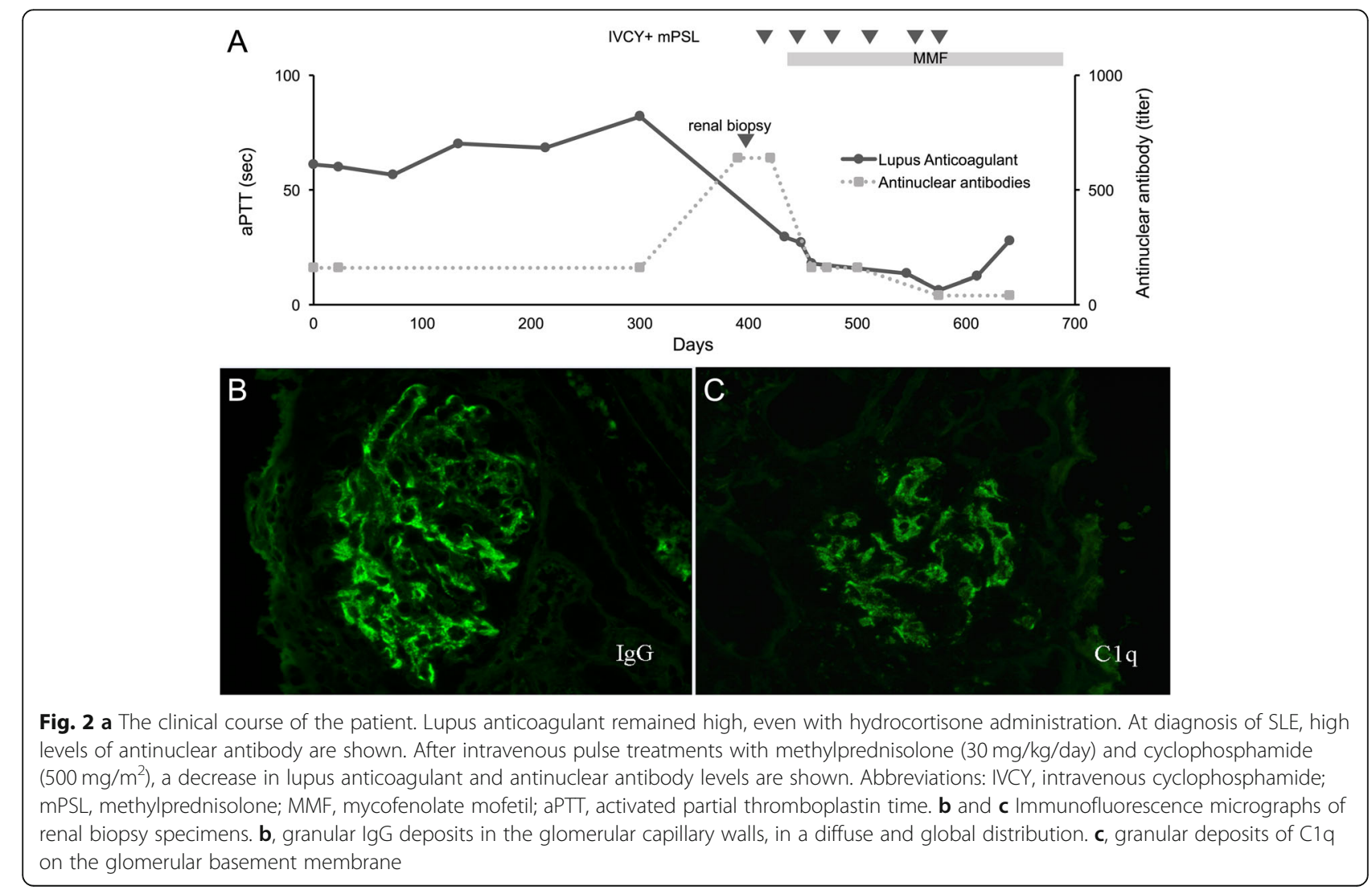


haemorrhage, and 2) we emphasize the importance of careful observation of the patient with autoantibodies, LA and ANA, because autoantibodies precede clinical manifestations of autoimmune diseases, such as SLE [9].

LAHPS is mainly found in children with LA and is accompanied by a decrease in plasma prothrombin activity due to IgM class anti-prothrombin antibody [3, 4]. LAHPS was reported by Bajaj in 1983, and the pathophysiology of LAHPS is thought to be an immune complex with prothrombin antibody, which is rapidly excreted from the blood, resulting in low prothrombin activity [10]. In our case, a decrease in prothrombin activity supports a similar pathophysiology. LAHPS-associated adrenal haemorrhage is rare; however, paediatricians should pay attention to this complication for unexplained or prolonged abdominal pain.

Adrenal failure due to adrenal haemorrhage is rare, but potentially fatal $[6,11]$. In childhood, it generally presents with nonspecific signs and symptoms, such as fatigue, malaise, abdominal pain, nausea, and vomiting, without hyperpigmentation. Therefore, diagnosis and treatment may often be delayed. Our case showed prolonged abdominal pain and deranged coagulation, and early recognition of adrenal insufficiency due to adrenal haemorrhage enabled early intervention. The pathophysiology of adrenal gland bleeding remains unclear. The adrenal gland comprises a rich arterial supply with a single vein limiting blood drainage; a thrombosed vein can result in progressive increase in arterial blood pressure [12].

Antibodies promoting thrombosis are known to be associated with autoimmune diseases, such as antiphospholipid syndrome, or to be produced in reaction to an acute infection, particularly in children [13, 14]. However, our patient developed SLE after 1 year, a development described less frequently than the opposite one [9, 15]. Moreover, the patient did not fit the SLICC diagnostic criteria for SLE, nor is haemorrhage, with the partial exception of alveolar haemorrhage, a typical presentation of SLE. However, autoantibodies, including LA and ANA, persisted [16]. The development of autoantibodies has been reported to precede clinical manifestations of autoimmune diseases, such as SLE [9]. Renal dysfunction was also observed when SLE was diagnosed in our case. Therefore, we emphasize that the finding of autoantibodies in a patient with coagulation disorders should be followed by longterm monitoring.

In conclusion, the development of acute adrenal failure due to bilateral adrenal haemorrhage in the context of LAHPS is a rare, but life-threatening event that should be recognized and treated early. Our case stresses the importance of careful observation of the patient with LA and ANA.

\section{Abbreviations}

LAHPS: Lupus anticoagulant-hypoprothrombinemia syndrome; LA: Lupus anticoagulant;" SLE: Systemic lupus erythematosus; CRP: C-reactive protein; aPTT: Activated partial thromboplastin time; IgM: Immunoglobin $\mathrm{M}$; IgG: Immunoglobin G; ANA: Anti-nuclear antibody; dsDNA: Double-stranded DNA; SLICC: Systemic lupus international collaborating clinics

\section{Acknowledgements}

The authors wish to thank the medical editor from the Division of Education for Clinical Research at the NCCHD for editing this manuscript.

\section{Authors' contributions}

$\mathrm{AS}$ and $\mathrm{Al}$ conceived the study and wrote the manuscript. $\mathrm{MO}, \mathrm{AH}, \mathrm{KT}$, and Al treated the patient. $A S, A l, Y l$, and $K N$ were responsible for clinical input and data collection. All authors have read and approved the final manuscript.

\section{Authors' information}

Not applicable.

\section{Funding}

This study was supported in part by a grant from the National Center for Child Health and Development, grant numbers 29-8 and 2020C-5.

\section{Availability of data and materials}

All relevant data were included in this case study.

\section{Declarations}

Ethics approval and consent to participate

In Japan, a case report does not require ethics approval. Our study adhered to the Ethical Guidelines for Medical and Health Research Involving Human Subjects established by the Japanese government.

Consent for publication

The patient and the parents provided consent to publish.

\section{Competing interests}

The authors declare that they have no competing interests.

\section{Author details}

${ }^{1}$ Center for Postgraduate Education and Training, National Center for Child Health and Development, NCCHD, Tokyo, Japan. ${ }^{2}$ Children's Cancer Center, National Center for Child Health and Development, Setagaya-ku, Tokyo 157-8535, Japan. ${ }^{3}$ Division of Nephrology and Rheumatology, NCCHD, Tokyo, Japan. ${ }^{4}$ Division of Endocrinology and Metabolism, NCCHD, Tokyo, Japan. ${ }^{5}$ Division of Hematology, NCCHD, Tokyo, Japan. ${ }^{6}$ Department of Pediatrics, Nara Medical University, Kashihara, Nara, Japan. ${ }^{7}$ Department of Internal Medicine, School of Dentistry, Health Sciences University of Hokkaido, Ishikari-Tobetsu, Hokkaido, Japan.

Received: 1 September 2020 Accepted: 9 March 2021

Published online: 17 March 2021

\section{References}

1. Pengo V, Tripodi A, Reber G, Rand JH, Ortel TL, Galli M, et al. Update of the guidelines for lupus anticoagulant detection. J Thromb Haemost. 2009;7(10): 1737-40.

2. Mulliez SM, De Keyser F, Verbist C, Vantilborgh A, Wijns W, Beukinga I, et al. Lupus anticoagulant-hypoprothrombinemia syndrome: report of two cases and review of the literature. Lupus. 2015;24(7):736-45.

3. leko M, Yoshida M, Naito S, Ohmura K, Takahashi N. Lupus anticoagulanthypoprothrombinemia syndrome and similar diseases: experiences at a single center in Japan. Int J Hematol. 2019;110(2):197-204.

4. Mazodier K, Arnaud L, Mathian A, Costedoat-Chalumeau N, Haroche J, Frances $C$, et al. Lupus anticoagulant-hypoprothrombinemia syndrome: report of 8 cases and review of the literature. Medicine (Baltimore). 2012; 91(5):251-60.

5. Pilania RK, Suri D, Jindal AK, Kumar N, Sharma A, Sharma P, et al. Lupus anticoagulant hypoprothrombinemia syndrome associated with systemic 
lupus erythematosus in children: report of two cases and systematic review of the literature. Rheumatol Int. 2018;38(10):1933-40.

6. Ramon I, Mathian A, Bachelot A, Hervier B, Haroche J, Boutin-Le Thi Huong $D$, et al. Primary adrenal insufficiency due to bilateral adrenal hemorrhageadrenal infarction in the antiphospholipid syndrome: long-term outcome of 16 patients. J Clin Endocrinol Metab. 2013;98(8):3179-89.

7. Matsumoto T, Nogami K, Shima M. A combined approach using global coagulation assays quickly differentiates coagulation disorders with prolonged aPTT and low levels of FVIII activity. Int J Hematol. 2017;105(2): 174-83.

8. Petri M, Orbai AM, Alarcón GS, Gordon C, Merrill JT, Fortin PR, et al. Derivation and validation of systemic lupus international collaborating clinics (SLICC) classification criteria for systemic lupus erythematosus. Arthritis Rheum. 2012;64(8):2677-86.

9. Ma WT, Chang C, Gershwin ME, Lian ZX. Development of autoantibodies precedes clinical manifestations of autoimmune diseases: a comprehensive review. J Autoimmun. 2017;83:95-112.

10. Bajaj SP, Rapaport SI, Fierer DS, Herbst KD, Schwartz DB. A mechanism for the hypoprothrombinemia of the acquired hypoprothrombinemia-lupus anticoagulant syndrome. Blood. 1983;61(4):684-92.

11. Gerner P, Heldmann M, Borusiak P, Bures V, Wirth S. Adrenal failure followed by status epilepticus and hemolytic anemia in primary antiphospholipid syndrome. Thromb J. 2005;3(1):6.

12. Aldaajani H, Albahrani S, Saleh K, Alghanim K. Bilateral adrenal hemorrhage in antiphospholipid syndrome. Anticoagulation for the treatment of hemorrhage. Saudi Med J. 2018;39(8):829-33.

13. Kato M, Hisada R, Atsumi T. Clinical profiles and risk assessment in patients with antiphospholipid antibodies. Expert Rev Clin Immunol. 2019;15(1):7381

14. Valerio L, Riva N. Head, neck, and Abdominopelvic septic thrombophlebitis: current evidence and challenges in diagnosis and treatment. Hamostaseologie. 2020;40(3):301-10.

15. Veres K, Szodoray P, Szekanecz Z, Lakos G, Kiss E, Laczik R, et al. Clinical and immunoserological characteristics of the transition from primary to overlap antiphospholipid syndrome. Lupus. 2010;19(13):1520-6.

16. Ta R, Celli R, West AB. Diffuse alveolar hemorrhage in systemic lupus erythematosus: histopathologic features and clinical correlations. Case Rep Pathol. 2017;2017:1936282.

\section{Publisher's Note}

Springer Nature remains neutral with regard to jurisdictional claims in published maps and institutional affiliations.

Ready to submit your research? Choose BMC and benefit from:

- fast, convenient online submission

- thorough peer review by experienced researchers in your field

- rapid publication on acceptance

- support for research data, including large and complex data types

- gold Open Access which fosters wider collaboration and increased citations

- maximum visibility for your research: over $100 \mathrm{M}$ website views per year

At $\mathrm{BMC}$, research is always in progress.

Learn more biomedcentral.com/submissions 